\title{
Seed loss and volunteer seedling establishment of rapeseed in the northernmost European conditions: potential for weed infestation and GM risks
}

\author{
Pirjo Peltonen-Sainio ${ }^{1}$, Katri Pahkala ${ }^{1}$, Hannu Mikkola² and Lauri Jauhiainen ${ }^{1}$ \\ ${ }^{1}$ MTT Agrifood Research Finland, Plant Production Research, FI-31600 Jokioinen, Finland \\ ${ }^{2}$ University of Helsinki, Department of Agricultural Sciences, P.O. Box 28, FI-00014 University of Helsinki, Finland \\ e-mail: pirjo.peltonen-sainio@mtt.fi
}

\begin{abstract}
Rapeseed soil seed bank development and volunteer plant establishment represent substantial risk for crop infestation and GM contamination. This study was designed to complement such investigations with novel understanding from high latitude conditions. Four experiments were designed to characterise seed loss at harvest, persistence, viability and capacity for volunteer seedling establishment, as well as impact of management measures on soil seed bank dynamics. Oilseed rape was the primary crop investigated due to the availability of GM cultivars and because of the increasing importance. Harvest losses and soil seed bank development were significant. Volunteer seedlings emerged at reasonably high rates, especially in the first autumn after harvest, but about $10 \%$ of buried seeds maintained their viability for at least three years. Soil incorporation methods had no major effect on numbers of volunteer seedlings, but herbicide treatments controlled volunteer seedlings efficiently, though not completely, due to irregular timing of seedling emergence.
\end{abstract}

Key words: dormancy, GM, oilseed rape, seedling soil seed bank, spring sown crop, turnip rape, weed

\section{Introduction}

In the northernmost European growing conditions, represented by Finland, turnip rape (Brassica rapa L.) and oilseed rape (B. napus L.) (hereafter referred to as rapeseed) are grown for oil and protein production. The area under rapeseed has ranged from 3 to $7 \%$ of total agricultural land area during the 2000s. Due to the limited number of crops available for crop rotations in these regions, rapeseed represents an important means to increase diversity of cropping systems (Peltonen-Sainio and Niemi 2012). Spring rapeseed is grown mainly and winter types only sporadically due to harsh winter conditions. This is contrary to the situation elsewhere in Europe where winter rapeseed is the dominant crop, even in southern Sweden (Peltonen-Sainio et al. 2009a). Canada and Finland are thereby the only countries that produce rapeseed at Boreal zone (Rubel and Kottek 2010) and rely on spring types. However, climate in Finland is more marine contrary to Canadian continental climate of prairies and furthermore, northern limit for crop production is about 1000 kilometres further south in Canada than in Finland (Solantie 2012). This associates with noteworthy difference in day length which is close to three hours longer in Finland at Summer Solstice (www.gaisma.com, Jokioinen and Saskatoon compared as examples). In such northern agroecosystems germination, growth and development of rapeseed take place in exceptional climatic conditions and constraints (Trnka et al. 2011) that likely influence formation and persistence of volunteer seed bank in the soil and germination dynamics of seeds and thereby, the risks of weed infestation and GM contamination, escape and/or gene flow to nature and non-GM crops.

Rapeseed sheds some of its mature seeds during pod dehiscence prior to harvest. This is a negative feature, but seed losses during combine harvesting are even more substantial (Pahkala and Sankari 2001, Ilobson and Bruce 2002, Gulden et al. 2003, Lutman et al. 2005). Because rapeseed can develop secondary dormancy, the persistence of seeds in the soil can vary (Pekrun et al. 2006). Seed shattering is generally more common for oilseed rape than for turnip rape, but is especially so when optimal harvest time has passed, i.e. seed is fully mature and pods start to dehisce (Pahkala and Sankari 2001). Heavy rains and winds tend to increase seed shedding (Pahkala and Sankari 2001) along with bird attack (Lutman et al. 2005), branching-induced uneven ripening of pods, and chafing of plants against each other in dense stands. Seed shedding causes economic losses and may even affect quality in the case that the shed seeds are the most fully matured with low chlorophyll content. The economic importance of seed loss may be particularly severe in Finland, where rapeseed yields are modest, often ranging around 1300 $\mathrm{kg} \mathrm{ha}^{-1}$ (Peltonen-Sainio et al. 2007). 
Rapeseed is not only an important crop but also a noteworthy weed that competes with the primary crop and can cause significant yield losses in it (Vollman et al. 2010). Rapeseed is nowadays a weed also at high latitudes (Salonen et al. 2011). Rapeseed was introduced into Finnish cropping systems about four decades ago. Weed populations have responded to changes in management practices, tending to be higher in the 1990s than in the 1980s (Hyvönen et al. 2003), but are now at a constant level (Salonen et al. 2013). In Finland, volunteer rapeseed plants were found on $9 \%$ of surveyed farmers' fields across studied regions in 1997-1999 and on 5\% in 2007-2009, but the figure ranged from zero to $27 \%$ depending on region and year. As rapeseed is not frequently included in crop rotations, but cereal monocultures are typical, this finding emphasizes the potential of rapeseed to produce volunteers as does the fact that survey samplings were carried out late in the growing season, after early summer herbicide treatments that control rapeseed effectively (Salonen et al. 2011) and therefore, only part of the emerged volunteers were identified in farmers' fields.

Seed shedding represents another potential concern, the risk of GM contamination in addition to the risk of gene flow from transgenic rapeseed cultivars (Krato and Petersen 2012). Rapeseed and potato (Solanum tuberosum L.) are the sole major crops that are adapted for cultivation at above $60{ }^{\circ} \mathrm{N}$ latitude and for which there are $\mathrm{GM}$ cultivars, if approved by the European Union (Stein and Rodriguez-Cerezo 2009). Herbicide tolerance is the main trait inserted in GM rapeseed cultivars, but seed oil composition and disease resistance are additional traits (Stein and Rodriguez-Cerezo 2009). Seed shattering and volunteer seedling establishment of rapeseed therefore represent a notable risk for GM contamination. Risks vary depending on climatic conditions and cropping systems, but introduction of GM rapeseed, especially when conferring herbicide tolerance, is likely to change some cropping, handling and storage practices (Krato and Petersen 2012).

This study aimed to quantify the risk of spring rapeseed seed shedding inducing yield losses in Finland and to characterize the dynamics and volumes of seedling establishment after harvest. Soil management techniques were taken into account in order to understand better the potential of rapeseed to become a weed and to foresee potential risks for introducing GM cultivars into high latitude cropping systems. Spring oilseed rape was primarily investigated due to the current availability of GM cultivars and because it has potential for expansion (PeltonenSainio et al. 2009b, 2009c), while spring turnip rape was included in some of the experiments because it is the dominant oil crop in the country.

\section{Material and methods}

\section{Experimental arrangements and measurement}

Four field experiments, differing in focus, timing and duration, were arranged in Jokioinen $\left(60^{\circ} 49^{\prime} \mathrm{N}, 23^{\circ} 28^{\prime} \mathrm{E}\right)$ in southern Finland during 2004-2007. One of the experiments focused on seed loss during threshing and thereby, generation of a volunteer seed bank in the soil, while the others focused on viability, germination and emergence of rapeseed according to conditions and treatments. All the experiments included an oilseed rape cultivar, but in some cases turnip rape also. In general, 'Wildcat' was used as a model oilseed rape cultivar, though genotypic differences may contribute to sensitivity to pod shattering (Wang et al. 2007) as well as dormancy induction and thereby, seed longevity in the soil (Nagel et al. 2011, Haile and Shirtliffe 2014).

Seed losses during threshing were measured for turnip rape (cultivar 'Kulta') on 7 September 2005 and for later maturing oilseed rape (cultivar 'Wildcat') on 16 September 2005. The closely located fields of turnip rape and oil-

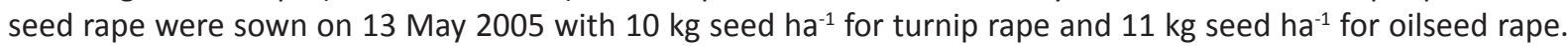
The crop stands received pesticides as needed and the major growth stages were recorded. Seed losses were determined according to ISO 8210 standard (1989) at different capacity levels of the Sampo 690 combine harvester by harvesting sample areas of $3.5 \mathrm{~m} \times 100 \mathrm{~m}$ at the most optimal time after maturation. Figures 1 and 2 illustrate the standardized combine harvesting processes. The test combine had adjustable sieves that were adjusted before the test according to the instructions of the combine manufacturer. The size of the holes of the sieves and the volume and direction of air flow were adjusted so that they provided an ideal combination to avoid unnecessary combine harvesting losses. The speed of the combine harvester was increased stepwise from $0.5 \mathrm{~m} \mathrm{~s}^{-1}$ upwards as far as the header of the combine was blocked. The speed of a single test run was always constant, but it was increased test by test to gain the maximum capacity of the combine. The highest speed was $1.1 \mathrm{~m} \mathrm{~s}^{-1}$. A combine harvesting test was considered to be successful when the combine harvester worked without blocking. In the case of blocking, the combine harvester had to be stopped before the end of the test lane and harvesting losses were not measured, i.e., an unsuccessful test did not meet the requirements of the ISO 8210 standard. Blocking may appear e.g. at the header, the drum, straw walkers or some conveyor. 


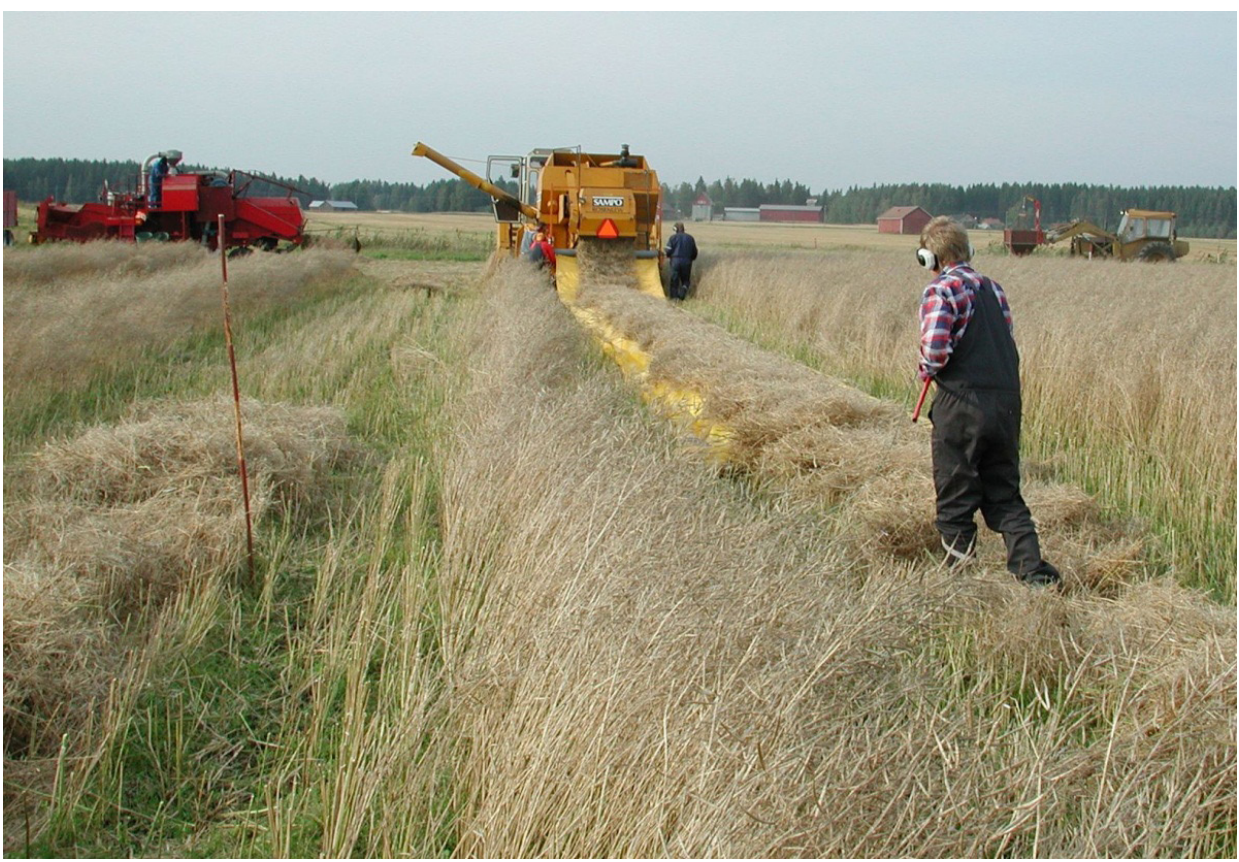

Fig. 1. A combine harvesting test of the spring turnip rape is going on in accordance with ISO 8210 standard. Material from straw walkers was collected on a $25 \mathrm{~m}$ long tarpaulin and material from sieves was collected into a bag at the same time (the bag can't be seen because it was coupled to the sieve unit and it was located below the tarpaulin). (Photograph: Lippo Sundberg).

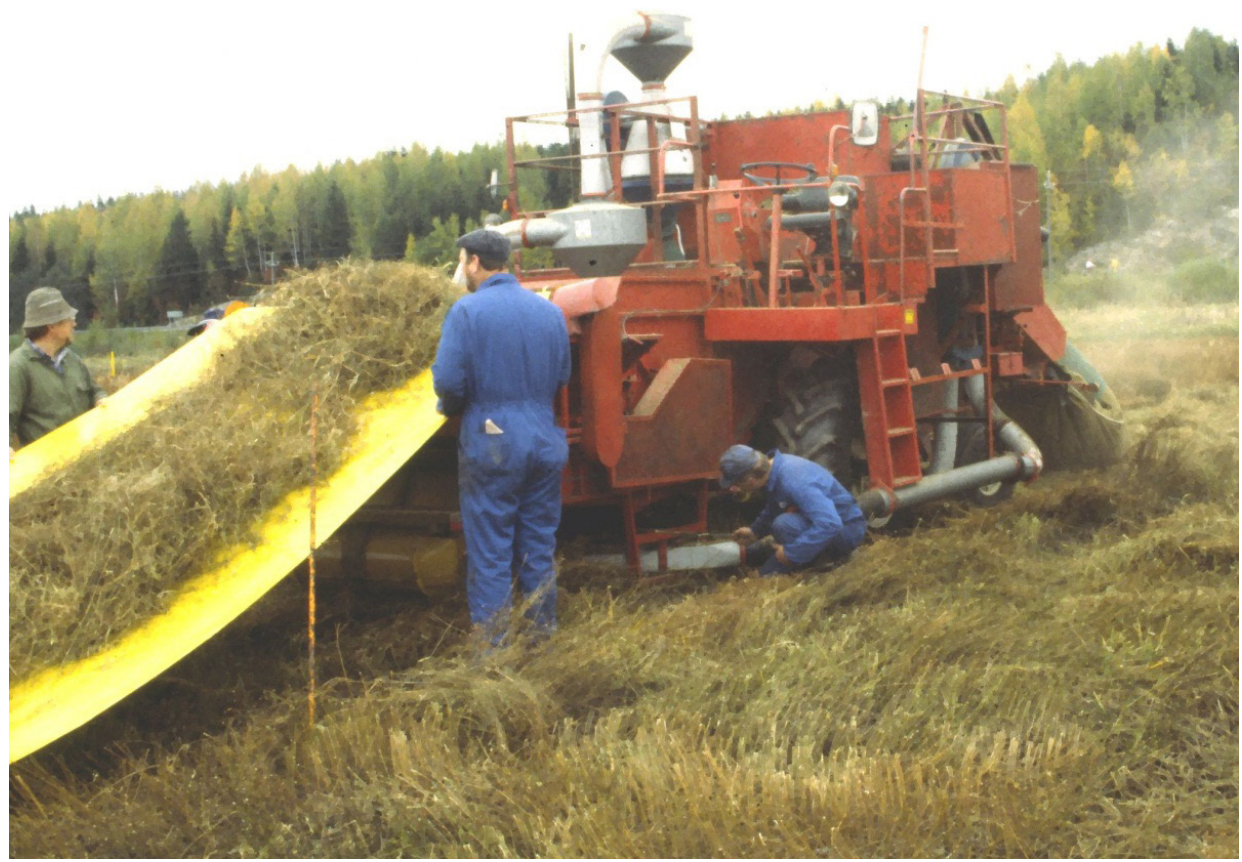

Fig. 2. A modified combine harvester was used to recombine material from straw walkers. Losses from the drum and from the straw walkers were defined in this test. After this test material from sieves was recombined in order to define losses from the sieve unit. Note a bag behind the combine harvester. Material going through the combine was weighted after the test in order to define the mass of the material other than grain. (Photograph: Matti Haverinen).

The mass of material other that grains, i.e. straw and chaff, has an impact on where overloading appears first. Furthermore, the condition of the crop has an impact on overloading. During the successful test runs the speeds of the combine were $0.52,0.70,0.86,0.88$, and $1.09 \mathrm{~m} \mathrm{~s}^{-1}$ for turnip rape and $0.53,0.53,0.85,0.88,0.98$, and $1.08 \mathrm{~m}$ $\mathrm{s}^{-1}$ for oilseed rape. Yield losses (kg per unit sampled area) were measured from straw walkers, sieves and drums 
of the harvesters again according to ISO 8210 standard (1989), and from the header of a harvester by using five metal collector $(10 \mathrm{~cm} \times 100 \mathrm{~cm})$ placed between the wheels right before combining.ISO 8210 standard (1989) gives detailed instructions for catching and handling crop material discharged from the combine for measuring harvesting losses. The standard does not, however, give instructions for measuring header losses but a similar procedure was applied here as described by Varis and Pehkonen (1989). Seed yield (kg ha $\left.{ }^{-1}\right)$, straw yield $\left(\mathrm{kg} \mathrm{ha}^{-1}\right)$ and seed moisture content (\%) were measured and harvest losses (\%) calculated by dividing seed loss by seed yield and multiplying by one hundred. Five successfully repeated harvests were carried out for turnip rape and six for oilseed rape from a total of ten. Unsuccessful harvesting trials, which are essential when ISO 8210 standard is followed, were dismissed due blockages of header and straw walker chamber as a result of overloading. In addition to determining the harvest losses for turnip rape and oilseed rape per se, with this experiment we aimed to mimic the extent of seed deposit in the soil seed bank.

Seed viability and readiness to germinate from different soil depths were studied for oilseed rape (cultivar 'Wildcat'). Non-GM cultivar was used as Crawley et al. (1993) demonstrated that invasiveness and persistence of transgenic oilseed rape did not differ compared with those for conventional cultivars. Seed used in the experiment was harvested from near field plot on 1 October 2004 and stored at $6{ }^{\circ} \mathrm{C}$ temperature until experiments were established. Net-like polyethylene bags with 100 seeds in each, without any soil to mix with, were buried at three soil depths, 0, 10 and $20 \mathrm{~cm}$ with four replicates on 5 October 2004 to mimic timing for harvest seed loss and the following soil ploughing bringing the seeds to different soil depths. Each seed bag was placed by hand to have as even contact to soil as possible. This also agreed with bags placed on soil surface. Each seed bag that was dug into three different soil depths represented a small plot of $25 \mathrm{~cm} \times 25 \mathrm{~cm}$. Seven timings for digging up the samples were considered as treatments, which were randomized for each of the four replicates. The experiment lasted until autumn 2007. For winter and spring months, daily measurements on soil temperatures at 0,10 and $20 \mathrm{~cm}$ soil depth were available from nearby experiments and are reported by Mustonen et al. (2009). Seeds were germinated for the first time on 11 November 2004 and thereafter twice a year (in spring and autumn) on 13 May and 10 October 2005, 12 May and 12 October 2006 and 2 May and 19 September 2007. Seed bags from different soil depths were dug up and seeds were placed on to moist blotting papers, which were placed under a glass cone (with ventilation hole) into a Jacobsen germination table having temperature and water level controllers, at day/night (light/dark) temperature of $30 / 20^{\circ} \mathrm{C}$. Germinated (normal and abnormal) and dead seeds were counted three and seven days after initiation of the germination test. After seven days of germination, the remaining hard seeds were lightly rubbed with fine sandpaper in order to break residual dormancy. The numbers of germinated and dead seeds were assessed three and seven days after rubbing treatment. Thereafter, the remaining seeds were stuck with a thin needle and again the number of germinated and decayed seeds was assessed. The number of hard seeds remaining in each sample was determined when the germination tests were finished, i.e. seven days after the needle treatment.

Capacity for seedling emergence of oilseed rape from different soil depths after spring sowing was monitored in an additional small-scale field experiment by sowing oilseed rape (cultivar 'Wildcat') in topsoil and at 2.5, 5.0, 10.0 and $20.0 \mathrm{~cm}$ on 17 May 2005. One hundred seeds were sown per treatment as a small field plot of $25 \mathrm{~cm} \times 25$ $\mathrm{cm}$ with four replicates. The number of emerged seedlings was counted from one week after sowing until $12 \mathrm{July}$, three times per week in the early season and once a week later in the season until no more seedlings emerged. Emerged seedlings were uprooted after each measurement. We intended to follow up the experiments for two years, but secured results on emerged seedlings only for the year of sowing. With this experiment we aimed to monitor the dynamics of oilseed rape seedling appearance according to soil depth at which the seeds were buried.

Soil preparation method and herbicide use effects on seedling emergence of oilseed rape as a volunteer weed in a barley crop was studied during the period of 2004-2007. To simulate harvesting losses, oilseed rape (cultivar 'Wildcat') seed with high viability (98\%) at $63 \mathrm{~kg} \mathrm{ha}^{-1}$ (corresponding to 1425 seeds $\mathrm{m}^{-2}$ ) was broadcast (Tume 2000, Nokka-Tume Oy, Finland) on to a soil surface of the study area with oat (Avena sativa L.) stubble on 4 October 2004 to imitate harvest losses. The experiment was arranged as split-plot design with four replicates: three combinations of soil preparation and cultivation methods were main block treatments and control and herbicide treatment sub-blocks randomized within in each main block. Plot size was $5 \times 10 \mathrm{~m}$. Soil preparation and cultivation treatments following oilseed rape seed scattering were: 1) ploughing in 11 November 2004 followed by harrowing and sowing of barley (Hordeum vulgare L., cultivar 'Inari', $200 \mathrm{~kg} \mathrm{ha}^{-1}$ ) in the following spring 2005, 2) direct drilling of barley in spring 2005 with a Väderstad Rapid (Väderstad, Sweden) at the same seeding rate and 3) fallow with oat stubble. In 2006, wheat (Triticum aestivum L., cultivar 'Kruunu') and in 2007 barley (cultivar 'Annabell') were again either 1) sown after autumn ploughing (26 October 2005, 11 September 2006) and spring harrowing or 2) direct drilled depending on treatment, at $200 \mathrm{~kg} \mathrm{ha}^{-1}$. Sowing/drilling times were 13 May 2005, 12 May 2006 and 
9 May 2007. Fallow remained as such throughout the study period and was treated with herbicide (glyphosate $1.44 \mathrm{~kg} \mathrm{ha}^{-1}$ a.i.) on 29 October 2004, 7 June 2005, 19 June 2006 and 14 June 2007. For cereals, herbicides were sprayed at the same time as for fallow by using glyphosate (1.44 $\mathrm{kg} \mathrm{ha}^{-1}$ a.i.) in 2004 and a commercial mixture of dichloprop (1200 $\mathrm{g} \mathrm{ha}^{-1}$ a.i.) and MCPA (600 $\mathrm{g} \mathrm{ha}^{-1}$ a.i.) for the remaining years. Seedlings were counted in two circles of $0.25 \mathrm{~m}^{2}$, both set permanently on each plot in autumn 2004, and weekly during the growing periods of 2005, 2006 and 2007. Seedlings were removed from each circle immediately after counting.

\section{Statistical analyses}

The selected statistical model was based on split-plot experimental design: three combinations of soil preparation and cultivation methods (S) were applied to main plots, while herbicide treatment and control $(\mathrm{H})$ were sub-plot treatment. Seedling counts were repeated three times during the study. The following repeated measurements ANOVA for a split-plot design was used:

$y_{i j k l}=\mu+B_{i}+S_{j}+S x B_{i j}+H_{k}+S x H_{j k}+T_{1}+T x B_{i l}+T x S_{j l}+T x S x B_{i j l}+T_{x H} H_{k l}+T x S x H_{j k l}+\varepsilon_{i j k l}$

where $B_{i}, S_{x B} B_{i j}, T_{x} B_{i,}, T x S x B_{i j l}$ and $\varepsilon_{i j k l}$ are the random effects of the $i^{\text {th }}$ block $(i=1,2,3,4)$, block by main plot treatment interaction, block by measurement time interaction, block by main plot interaction, treatment by measurement time interaction and residual effect, respectively. All the random effects were assumed to be mutually independent. Residuals from the same plot can be correlated and the unstructured correlation model was selected from potential models by likelihood-ratio test and the Akaike's information criterion. The unstructured correlation model allows that the random variation can vary from year to year. $\mathrm{S}_{\mathrm{j}}, \mathrm{H}_{\mathrm{k}}, \mathrm{T}_{1}, \mathrm{SxH}_{\mathrm{jk}}, \mathrm{TxS}_{\mathrm{j},}, \mathrm{TxH}_{\mathrm{kl}}$ and $\mathrm{TxSxH}_{\mathrm{jk} \mathrm{l}}$ represent fixed effects of main-plot treatment ( $j=$ three combinations of soil preparation and cultivation methods), subplot treatment ( $k=$ control, herbicide treatment), measurement time $(I=2004,2005,2006)$ and their interactions.

Statistical model for seed viability data based on the randomized complete block design. Arc sine square-root transformation of data was done before statistical analysis to make the distribution normal. Three soil depths, 0 , 10 and $20 \mathrm{~cm}$, were used as a repeated factor in the used model:

$y_{i j k l}=\mu+B_{i}+T_{j}+D_{1}+B x D_{i l}+T x D_{j l}+\varepsilon_{i j k}$

where $B_{i}, B x D_{i l}$ and $\varepsilon_{i j k}$ are the random effects of the ith block (i=1,2,3,4), block by depth, and residual effect, respectively. All the random effects were assumed to be mutually independent. Residuals from the same plot can be correlated and the unstructured correlation model was selected from potential models by likelihood-ratio test and the Akaike's information criterion. $T_{j}, D_{1}$ and $T_{x D_{j l}}$ represent fixed effects of treatment ( $j=A u t u m n ~ 2004, \ldots, A u-$ tumn 2007), depth (I=spil surface, $10 \mathrm{~cm}$ depth, $20 \mathrm{~cm}$ depth), and their interaction, respectively. Both statistical models were fitted using the REML-estimation method and SAS/MIXED software (version 9.1.3).

Data of capacity for seedling emergence of oilseed rape from different soil depths did not need any complex statistical modelling because all differences were clear. Descriptive statistics were used (mean + standard deviation). Arc sine transformation was done before analysis. Used statistics were transformed back to the original scale.

\section{Results}

\section{Seed losses during threshing}

The threshing experiment was arranged to get an estimate of harvest losses and the available seed bank for volunteer seedlings. Pre-harvest seed loss was not investigated in this study as earlier thorough studies have reported how significant the pre-harvest losses are on turnip rape and oilseed rape depending on maturation, timing of harvest and weather conditions (Pahkala and Sankari 2001).

Our study indicated that yield losses from combine harvesting ranged from 40 to $60 \mathrm{~kg}$ seed ha-1 for turnip rape and up to $100 \mathrm{~kg} \mathrm{ha}^{-1}$ for oilseed rape, while the figures for the header, caused by vibration of the crop when harvested, were $37 \mathrm{~kg}$ seed ha-1 and $51 \mathrm{~kg}^{-1}$ seed ha ${ }^{-1}$, respectively (Table 1). Harvesting losses corresponded in total to ca. 3500-4000 volunteer seeds $\mathrm{m}^{-2}$ in rapeseed as 1000 seed weights averaged 2.24 and $4.15 \mathrm{~g}$ for turnip rape and oilseed rape, respectively. In the test threshing runs mean seed yield of turnip rape was $1920 \mathrm{~kg} \mathrm{ha}^{-1}$ and of oilseed rape $1980 \mathrm{~kg} \mathrm{ha}^{-1}$, both with reasonably high harvest indices. Most of harvest losses originated from combine harvester sieves, in the case of turnip rape, and from drums for oilseed rape. 
Table 1. Seed and straw yield at $9 \%$ moisture content $\left(\mathrm{kg} \mathrm{ha}^{-1)}\right.$ and seed losses during threshing (\%) of turnip rape and oilseed rape (number of seeds $\mathrm{m}^{-2}$ in parenthesis) in 2005. Ten test harvests were carried out, five of which were successful for turnip rape and six for oilseed rape.

\begin{tabular}{|c|c|c|c|c|c|c|}
\hline \multirow[t]{2}{*}{ Trait } & \multicolumn{3}{|c|}{ Turnip rape } & \multicolumn{3}{|c|}{ Oilseed rape } \\
\hline & Mean & Min & Max & Mean & Min & Max \\
\hline Seed yield (kg ha-1) & 1920 & 1760 & 2000 & 1980 & 1810 & 2090 \\
\hline Straw yield $\left(\mathrm{kg} \mathrm{ha}^{-1}\right)$ & 2050 & 1120 & 2680 & 1890 & 1550 & 2400 \\
\hline HI (\%) & 49.2 & 42.7 & 61.1 & 51.2 & 44.9 & 53.9 \\
\hline \multicolumn{7}{|l|}{$\begin{array}{l}\text { Combine harvesting } \\
\text { losses from: }\end{array}$} \\
\hline Drum (\%) & 0.68 & 0.21 & 1.33 & 1.82 & 0.70 & 3.49 \\
\hline Straw walkers (\%) & 0.11 & 0.08 & 0.14 & 0.25 & 0.04 & 0.47 \\
\hline Sieve (\%) & 1.82 & 1.49 & 2.19 & 0.93 & 0.45 & 1.91 \\
\hline Total (kg ha-1) & $50(1990)$ & 39 (1550) & $62(2470)$ & 67 (1840) & $43(1180)$ & $97(2660)$ \\
\hline \multicolumn{7}{|l|}{ Header losses: } \\
\hline Total $\left(\mathrm{kg} \mathrm{ha}^{-1}\right)$ & 37 (1470) & $19(760)$ & $60(2390)$ & $51(1400)$ & $22(600)$ & $108(2960)$ \\
\hline
\end{tabular}

Variation among sources of seed losses was high among test runs $(C V=0.69)$ as was also the variation in seed to straw ratio ( $C V=0.20)$. Threshing tests were carried out in 2005 when the growing season was otherwise relatively normal regarding monthly mean temperatures (Fig. 3) and precipitation, except during late summer when there was high precipitation followed by below normal precipitation during the harvest period (Fig. 4). The results for seed losses agreed well with the amounts of seed used to imitate harvest losses in the other experiments comparing soil preparation methods on volunteer seedling establishment.

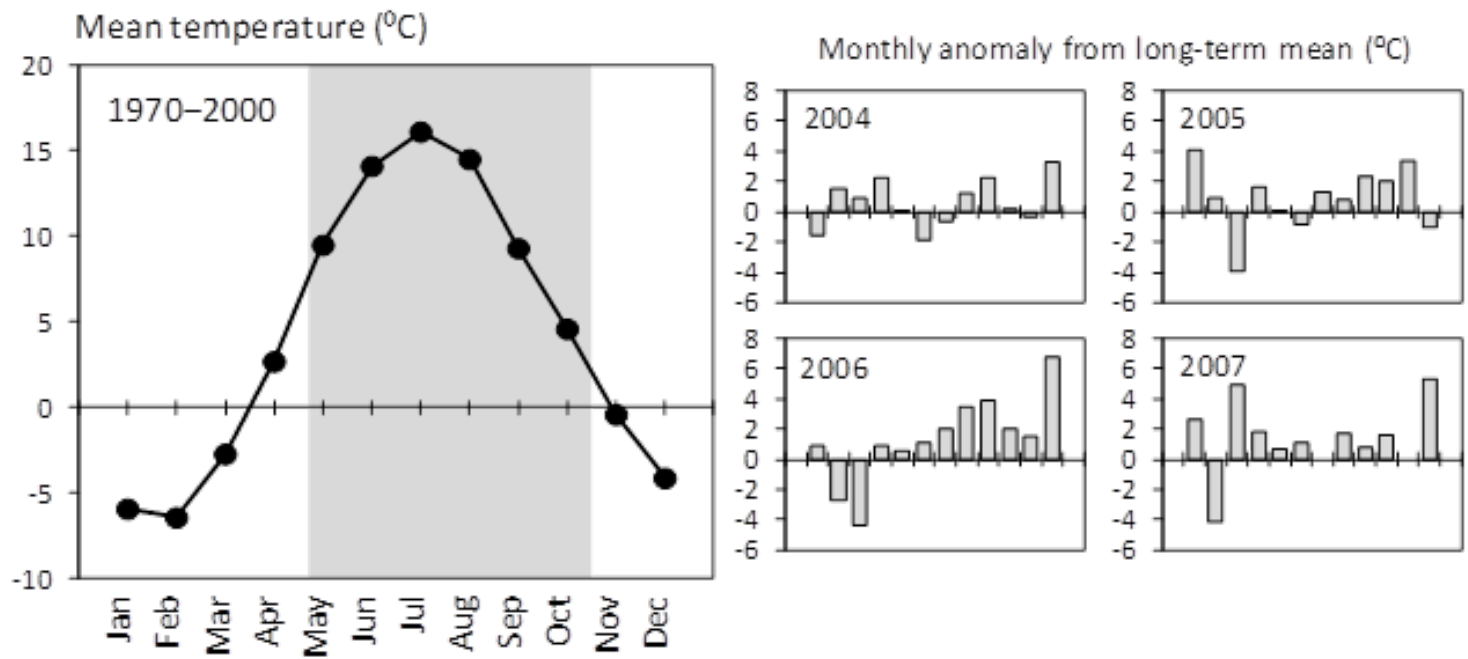

Fig. 3. Monthly mean temperatures $\left({ }^{\circ} \mathrm{C}\right)$ for the period of $1970-2000$ and difference from long-term mean during each study year from 2004 to 2007. Gray background indicates thermal growing season. Data from Finnish Meteorological Institute. 


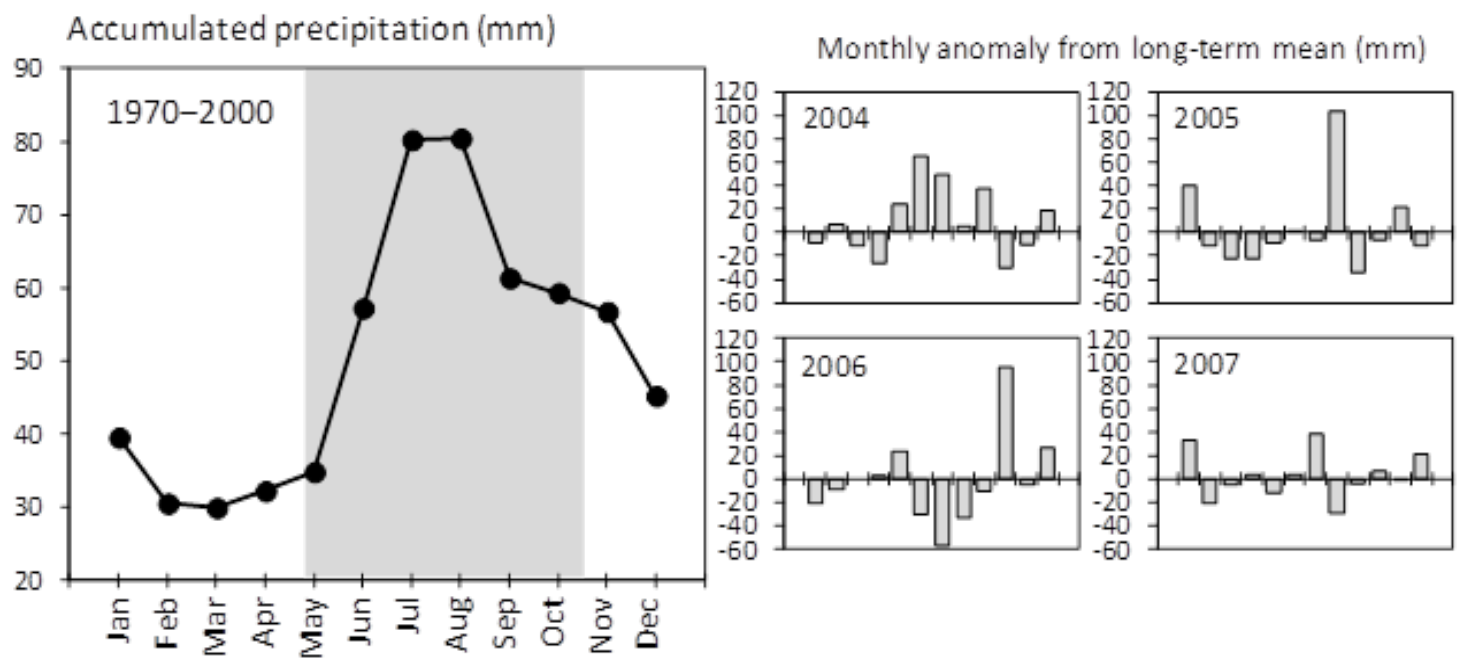

Fig. 4. Monthly mean for accumulated precipitation $(\mathrm{mm})$ for the period of $1970-2000$ and difference from long-term mean during each study year from 2004 to 2007. Gray background indicates thermal growing season. Data from Finnish Meteorological Institute.

\section{Readiness to germinate and capacity for seedling emergence from different soil depths}

When assessing the capacity of seeds from different soil depths to emerge as seedlings, we established that the share was highest (96\%) at $2.5 \mathrm{~cm}$ depth, while germination progressed similarly at $5 \mathrm{~cm}$, although it stagnated at $70 \%$ (Fig. 5). Only $39 \%$ of seeds produced seedlings at the soil surface and hardly any at $10 \mathrm{~cm}$ depth and none at $20 \mathrm{~cm}$. This experiment only described general ability of seeds to emerge seedlings from different soil layers.

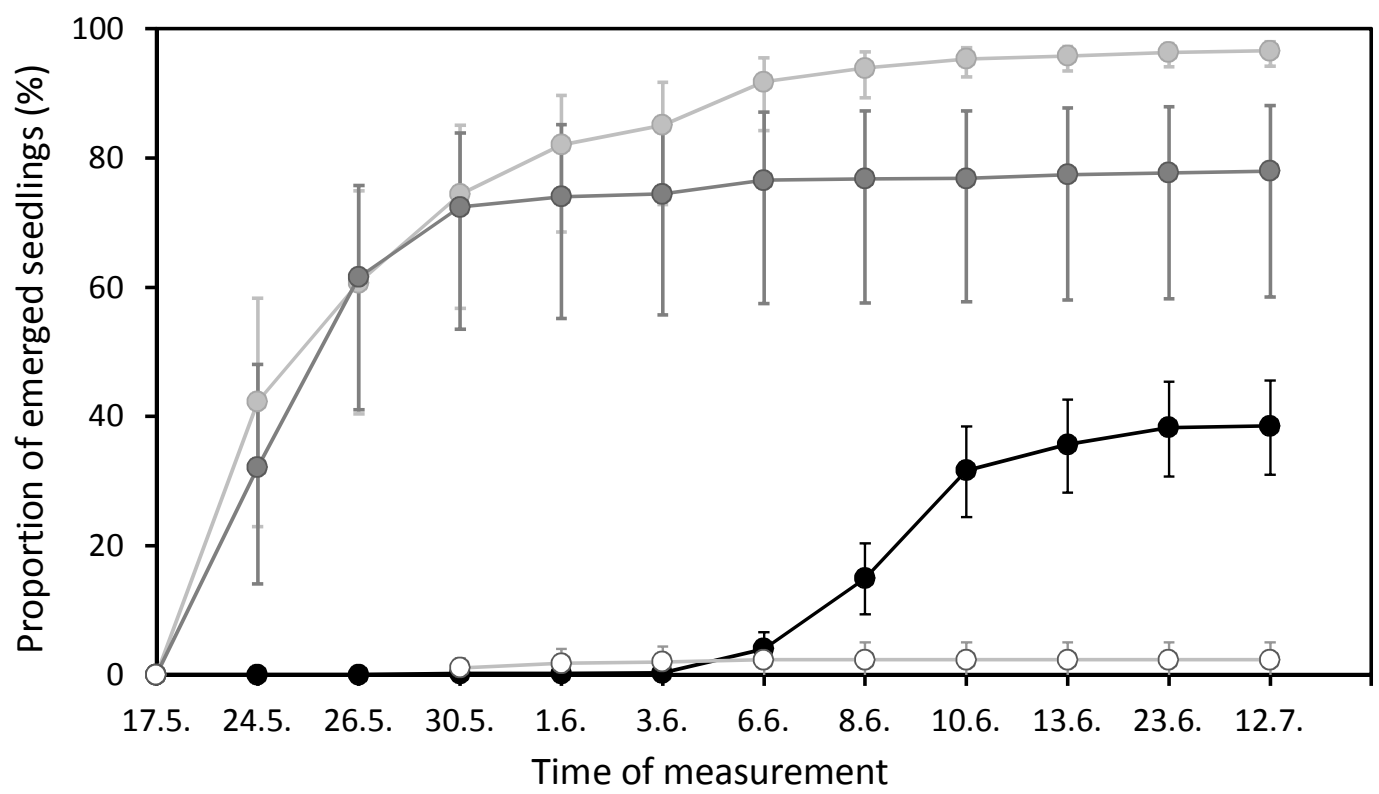

Fig. 5. The capacity of oilseed rape to germinate after being stored at different soil depths. Black circle indicates surface sowing, light gray $2.5 \mathrm{~cm}$, dark gray $5 \mathrm{~cm}$ and white circle $10 \mathrm{~cm}$ soil depth. None of the seeds located at 20 $\mathrm{cm}$ were able to germinate. Standard deviations are shown as vertical lines. 
An additional experiment took into account the persistence of seed viability over time when tested in recurrent autumns and springs. In that case, timing $\times$ soil depth interaction occurred for germination capacity $(p<0.001)$ : during the first two autumns and springs germination capacity was higher when seed bags were placed on the soil surface compared with at 10 or $20 \mathrm{~cm}$ depth (Fig. 6), however, this was not the case in spring $2006(p=0.52)$ and $2007(p=0.36)$. When placed on the soil surface, seeds lost their viability faster and only few seeds germinated two years later. The loss in germination capacity was rapid. In the first spring $15 \%$ of seeds located on the soil surface were dormant and hard. When seed lots were placed at 10 and $20 \mathrm{~cm}$ depths, germination ability remained at around 10\% throughout the study period (Fig. 6). Even though in autumn 2006 and 2007 germination differed significantly depending on soil depth $(p<0.001)$, germination was in general only negligible.

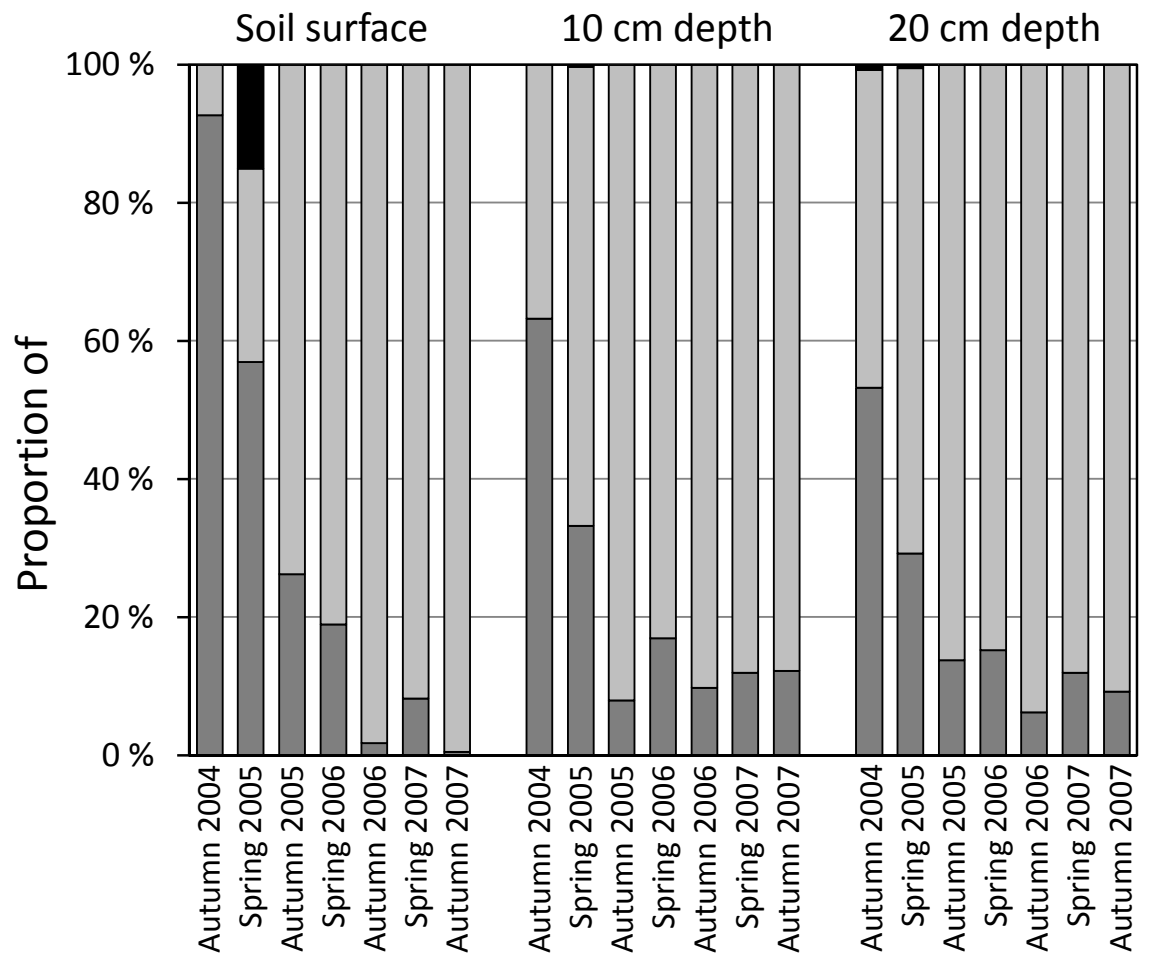

Fig. 6. Proportions (\%) of germinating (dark gray), dead (light gray) and hard seeds (black) in following autumns and springs, when placed on soil surface and at 10 and $20 \mathrm{~cm}$ soil depths. Differences between soil surface and at 10 and $20 \mathrm{~cm}$ soil depths were statistically significant $(p<0.001)$, except on spring $2006(p=0.52)$ and spring $2007(p=0.36)$.

\section{Management effects on seedling emergence}

When mimicking seed losses caused by combine harvesting and the subsequent dynamics of seedling establishment, it was evident that there were significant differences among years $(p<0.001)$. The vast majority $(90 \%)$ of the seeds that emerged as seedlings during the three-year monitoring period $\left(179 \mathrm{~m}^{-2}, \mathrm{SE}=12.4\right)$ were established in autumn 2004, i.e. prior to the first winter (Table 2). Only in 2004 was the number of emerging seedlings lower when herbicide was used (by $76 \mathrm{~m}^{-2}$ when compared with untreated control, SE =24.8). In the following years herbicide treatment did not affect seedling emergence rates as they were generally negligible: 19 seedlings $\mathrm{m}^{-2}$ in 2005 ( $\mathrm{SE}=24.8$ ), one $\mathrm{m}^{-2}$ in 2006 ( $\mathrm{SE}=0.4$ ) and none for 2007 onwards.

Soil management methods did not affect seedling establishment in 2004 and 2006, but in 2005 the highest number of seedlings emerged in the fallow treatment $\left(25 \mathrm{~m}^{-2}, \mathrm{SE}=3.4\right)$, then for direct drilling $\left(23 \mathrm{~m}^{-2}, \mathrm{SE}=3.4\right)$ and at least for ploughing $\left(9 \mathrm{~m}^{-2}, \mathrm{SE}=3.4\right)$. There was no significant year $\times$ soil management $\times$ herbicide use interaction $(p=0.26)$. When analyzed across years for fallow, herbicide treatment declined to 28 emerged seedlings $\mathrm{m}^{-2}$ $(\mathrm{SE}=13.4)$ compared with the control treatment. This was also the case with autumn ploughing (to 43 seedlings $\left.\mathrm{m}^{-2}, \mathrm{SE}=13.4\right)$, but there was no effect of direct drilling $(p=0.56)$. However, when only the year with the highest seedling emergence rates was studied separately (2004), we found that for fallow the difference between control and herbicide treatments was 77 seedlings $\mathrm{m}^{-2}(\mathrm{SE}=43.0)$, and for autumn ploughing $121 \mathrm{~m}^{-2}$ (SE=43.0) while it was non-significant for direct drilling $(p=0.24)$ (Table 2). 
Table 2. Significant differences across treatment interactions in experiments to study effects of soil management techniques and herbicide use on number of established rapeseed seedlings when measured at the end of autumn 2004,2005 and 2006 after scattering 1425 seeds $\mathrm{m}^{-2}$ evenly over the treatment plots at the time of oilseed rape harvests in 2004 . In 2007 no seedlings emerged. Accumulated proportion of emerged seedlings (\%) compared with scattered seeds are shown in parentheses.

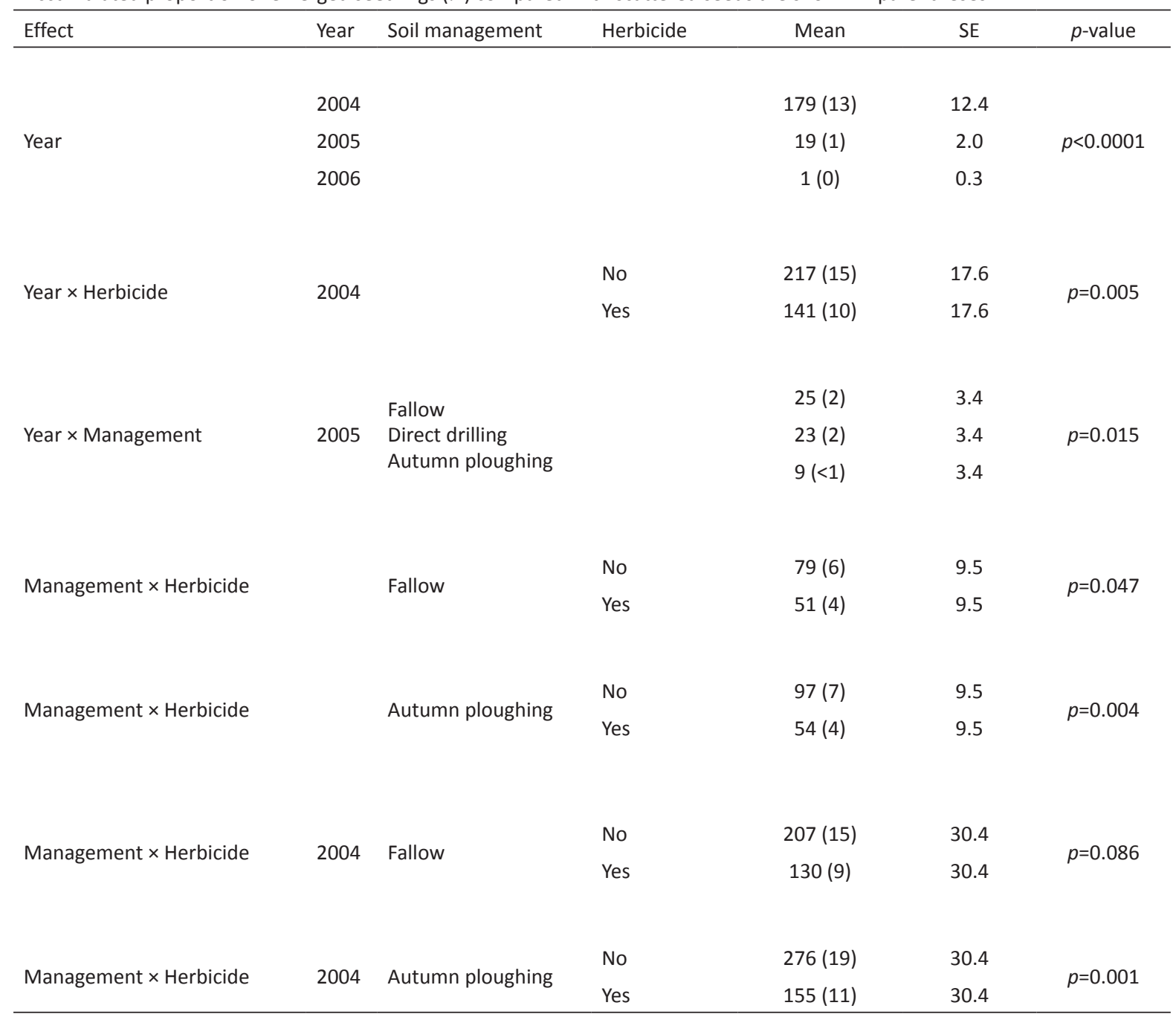

\section{Discussion}

Total combine harvesting losses were substantial, ranging from 39 to $62 \mathrm{~kg}$ seed ha-1 for turnip rape and 43 to 97 $\mathrm{kg} \mathrm{ha}^{-1}$ for oilseed rape (Table 1). High variation among harvest test runs was apparent, which highlights the uncertainties related to quantifying volunteer seed bank formation. These figures corresponded to 1740-2770 turnip rape (3.6 \% maximum yield loss) and 1040-2340 oilseed rape seeds $\mathrm{m}^{-2}$ (5.9\% maximum yield loss), which were comparable to losses reported for Canadian conditions (Gulden et al. 2003). However, a profound additional harvest loss was caused by header that vibrates crop stand right before combine harvesting. Such losses averaging even $37 \mathrm{~kg}$ seed ha- ${ }^{-1}$ for turnip rape and $51 \mathrm{~kg} \mathrm{seed} \mathrm{ha}^{-1}$ for oilseed rape corresponded to additional 1650 and 1230 volunteer seeds $\mathrm{m}^{-2}$, respectively. These losses together averaged $3500-4000$ volunteer seeds $\mathrm{m}^{-2}$ which are only near the lowest values that Lutman et al. (2005) reported for experiments carried out in the U.K.

The recorded difference in seed losses between U.K. and Finland may be attributable to cultivation of spring types and to the low rapeseed yields in Finland, which are not more than one third of those in the U.K. (Peltonen-Sainio et al. 2007). Interestingly, for a completely different Chinese cropping and harvesting system the maximum average seed yield loss was 6\% (Zhu et al. 2012). In either case, such a soil seed bank means considerable potential for rapeseed volunteers and weed infestation. This also reflects risks for GM contamination, in the case that GM cultivars are introduced into the cropping systems. Messean et al. (2007) demonstrated that only about 0.5 volunteers $\mathrm{m}^{-2}$, or even less, were sufficient to cross the threshold implemented by the European Union for GM contamina- 
tion. Risk of seed shattering, which is, however, marginal compared with that caused by harvesting (Pahkala and Sankari 2001), could be alleviated if GM cultivars were bred to be more pod shatter resistant by exploiting existing cultivar differences (Wang et al. 2007) or alleles from resistant genotypes of other Brassica species ( $\varnothing$ stergaard et al. 2006, Raman et al. 2014). This does not, however, represent a safeguard from losses caused by combine harvesting, which again needs technical solutions (such as additional conveyor-assisted header - llobson and Bruce 2002).

Seeds that germinated after dispersal did so mainly during the first autumn, corresponding to only about $13 \%$ of scattered seeds. In the following years scarcely any seedlings emerged (Table 2 ), though about $10 \%$ of seeds remained viable when buried in our experiments (Fig. 6). It is not, however, possible to judge whether seed predation occurred, e.g. by carabid beetles (Honek and Martinkova 2001), and whether newly emerged seedlings were killed by predators or unfavourable weather conditions prior to counting (Peltonen-Sainio et al. 2006). The soil seed bank is maintained by self-reproducing volunteer rapeseed plants, although their contribution is marginal compared with harvest losses (Gruber and Claupein 2007). Volunteer rapeseed populations are ephemeral without soil seed bank immigration (Beckie and Warwick 2010) though may persist for several years (Gulden et al. 2003) depending on genotypic differences in seed bank addition capacity (Haile et al. 2013). In Finland, only some fields are sufficiently favourable for rapeseed, and hence it is grown every fourth or fifth year in the same parcel to avoid soil borne diseases (Peltonen-Sainio et al. 2013). According to soil seed bank dynamics and longevity, the same fields are a permanent, though modest, source of rapeseed volunteers. The results that $5 \%$ of surveyed fields supported rapeseed weeds (Salonen et al. 2011) corresponds well with the proportion of fields that include rapeseed in their rotations. Along with potentially increasing areas under rapeseed production in the future (Peltonen-Sainio et al. 2009c, 2013), rapeseed volunteers may become more widespread. Our study was carried out with a model cultivar without exploring cultivar differences. However, there are potential to exploit genotypic differences in pod shatter resistance and also in seed longevity (Østergaard et al. 2006, Nagel et al. 2011, Raman et al. 2014), which may provide a means to alleviate future weed infestation and GM risks as well as harvest losses of rapeseed.

According to results of a survey carried out on farmers' fields in U.K., volunteer rapeseed plants were found in fields where rapeseed was not grown during the previous eight years (Debeljak et al. 2008). Andersen et al. (2010) demonstrated that in Danish conditions some rapeseed volunteers originated from cultivars grown 8-11 years earlier, which may represent a challenge for organic farming in particular. These examples highlight the longevity of soil seed banks. According to farmer interviews in Finland, rapeseed is an attractive crop alternative for organic crop rotations due to high market demand and functionality despite climatic risks and crop protection challenges (Hakala K., personal communication 4 June 2013). In light of our results on soil seed bank dynamics, rapeseed cultivation may represent long-term additional risks for weed infestation for organic production because volunteers are particularly hard to control mechanically from rows (Andersen et al. 2010).

Shattered seeds may also develop dormancy and survive for several years in the soil. In this study dormant, hard seeds were found in germination tests at high rates (15\%) only in the first spring after scattering the seeds on soil surface (Fig. 6). This was also recorded, but at low rates ( $<1 \%$ of seeds) at 10 and $20 \mathrm{~cm}$ depths. Darkness induces secondary dormancy (Lopez-Granados and Lutman 1998), but this did not occur in our studies, except in the case that secondary dormancy in the $10 \%$ of seeds that were viable for a couple of years in the soil (Fig. 6 ) was readily broken down when moved from soil to blotting-paper, representing the favourable conditions typical for a germination test. In general, recorded frequencies of secondary dormancy are comparable with those reported by Pekrun et al. (2006): 0-29\% in general, but declining to 0-5\% in moist years. Typically, in northern Europe humid conditions prevail in late summer and autumn (Peltonen-Sainio et al. 2009b), which reduces the likelihood for development of secondary dormancy in rapeseed (Lopez-Granados and Lutman 1998, Pekrun et al. 2006), in contrast to water stress and increase or variation in temperatures that induce it (Pekrun et al. 1997, Lopez-Granados and Lutman 1998, Momoh et al. 2002). On the other hand, pre-harvest conditions had only a relatively small affect on expression of dormancy (Gulden et al. 2004). The sensitivity for expression of secondary dormancy is, however, strongly affected by cultivar (Gulden et al. 2004, Schatzki et al. 2013) and is exhibited to a greater extent in winter (80\% at most) than in spring rapeseed (60\%) (Momoh et al. 2002). In our experiments only spring rapeseed was tested because winter types are not grown on a large scale in Finland. As heritability for secondary dormancy is high, selection for low expression of dormancy in rapeseed is a possibility for the future to reduce weed infestation capacity and GM contamination risk (Schatzki et al. 2013).

The soil bank of viable seeds declined prior to the first winter after harvest (Fig. 6). In general, harsh winter conditions at $60^{\circ} \mathrm{N}$ (Peltonen-Sainio et al. 2009b) kill spring rapeseed seedlings. The soil seed bank was depleted (60\%) within the first few months after harvest also in the U.K., and thereafter declined at lower rate, averaging $20 \%$ 
per year until an estimated loss of 95\% within nine years after harvest (Lutman et al. 2005). Lutman et al. (2005) did not establish any differences between conventional and GM cultivars in persistence of a soil seed bank, which suggests that the results of our study are likely to apply to GM risks represented by volunteer rapeseed plants.

Germination and emergence of volunteer rapeseed plants was affected by burial depth (Figs 5 and 6 ), as also demonstrated by Zhu et al. (2012). In our studies, seeds that were buried at 10 and $20 \mathrm{~cm}$ depth maintained ca. $10 \%$ germination ability by the end of the three-year study period (Fig. 6), but were not able to emerge as seedlings from such depths (Fig. 5). This indicates that a viable seed bank persisted in deep soil layers. According to Lutman et al. (2003), a mean of $1.8 \%$ of buried seeds survived 138 months when undisturbed. Persistence of soil seed banks was also demonstrated for western Canadian conditions, but interestingly when drought interfered in some years no volunteers emerged although they did reappear in later years (Beckie and Warwick 2010).

Our results showed that the volunteer seedling establishment rate was mainly affected by number of years after seed dispersal (Table 2), while differences in temperature and precipitation within and between years (Figs 3 and 4) played only a secondary role in seedling emergence. Moreover, soil incorporation methods (autumn ploughing, direct drilling, stubble fallow), had only minor effects: none in the first autumn despite the highest seedling emergence rates (i.e. immediately after seed dispersal), only negligible during the following year (Table 2), and none consequently. In northern European conditions, the time window for autumn ploughing is limited after harvest until winter approaches, and is interfered with by heavy rains. Therefore, postponed ploughing is not a feasible method to control seed bank formation at high latitude conditions contrary to the findings of Gruber et al. (2004, 2010) and Pekrun et al. (2006). Gruber et al. (2004) and Pekrun et al. (2006) also showed that in the case of zero tillage a viable soil seed bank did not form, but some robust volunteers were established that were not evident in our conditions. Nevertheless, herbicide treatments significantly decreased the number of volunteer rapeseed plants, the efficacy depending on year and soil incorporation method (Table 2). Full control is challenging as rapeseed seedlings emerge from the soil seed bank irregularly. This may be partly due to unfavourable soil temperatures as germination of rapeseed is very temperature sensitive (Peltonen-Sainio et al. 2006). Begg et al. (2006) concluded, according to their modelling exercises, that the thresholds for GM material in harvested crops could be sufficiently low within a couple of years after cultivation of GM cultivars, but only with rigorous and costly control of volunteers. Hence, they concluded that farms should differentiate either for production of conventional or GM cultivars (Begg et al. 2006), which seems also to be the best strategy for northern European agroecosystems if GM cultivars are introduced into cultivation.

In conclusion, our studies indicated that harvest losses of spring rapeseed averaged 3500-4000 volunteer seeds $\mathrm{m}^{-2}$ and the soil seed bank that was thereby generated was evidently significant. Seedlings, however, emerged at reasonably high rates of $13-19 \%$ in the first autumn after harvest, while about $10 \%$ of buried seeds maintained their viability for at least a couple of years. Due to having rapeseed in the rotation for every fourth or fifth year it is likely that vast majority of the soil seed bank is lost prior to new seed load caused by cultivating rapeseed again in rotation. Soil incorporation methods had no major effect on numbers of volunteer seedlings.

\section{Acknowledgements}

Technical assistance provided by research technicians and students at MTT Plant Production Research is gratefully acknowledged. The work was financed by the Academy of Finland (207485), the Ministry of Agriculture and Forestry and MTT as a part of the project GMOs and Genetic Pollution: Searching for Potential Solutions for Co-existence and Providing Recommendations for Management (ESGEMO programme).

\section{References}

Andersen, N.S., Rasmussen, J. \& Jørgensen, R.B. 2010. You reap what you sow - or do you? - volunteers in organic row-sown and broadcast-sown oilseed rape fields. European Journal of Agronomy 32: 121-126.

Beckie, H.J. \& Warwick, S.I. 2010. Persistence of an oilseed rape transgene in the environment. Crop Protection 29: 509-512.

Begg, G.S., Hockaday, S., Mcnicol, J.W., Askew, M. \& Squire, G.R. 2006. Modelling the persistence of volunteer oilseed rape (Brassica napus). Ecological Modelling 198: 195-207.

Crawley, M.J., Hails, R.S., Rees, M., Kohn, D. \& Buxton, J. 1993. Ecology of transgenic oilseed rape in natural habitats. Nature 363 : 620-623.

Debeljak, M., Squire, G.R., Demsar, D., Young, M.W. \& Dzeroski, S. 2008. Relations between the oilseed rape volunteer seedbank, and soil factors, weed functional groups and geographical location in the UK. Ecological Modelling 212: 138-146. 
Gruber, S., Bühler, A., Möhring, J. \& Claupein, W. 2010. Sleepers in the soil - Vertical distiribution by tillage and long-term survival of oilseed rape seeds compared with plastic pellets. European Journal of Agronomy 33: 81-88.

Gruber, S. \& Claupein, W. 2007. Fecundity of volunteer oilseed rape and estimation of potential gene dispersal by a practice-related model. Agriculture, Ecosystems \& Environment 119: 401-408.

Gruber, S., Pekrun, C. \& Claupein, W. 2004. Population dynamics of volunteer oilseed rape (Brassica napus) affected by tillage. European Journal of Agronomy 20: 351-361.

Gulden, R.H., Shirtliffe, S.J., Thomas, A.G. 2003. Harvest losses of canola (Brassica napus) cause large seedbank inputs. Weed Science 51: 83-86.

Gulden, R.H., Thomas, A.G. \& Shirtliffe, S.J. 2004. Relative contribution of genotype, seed size and environment to secondary seed dormancy potential in Canadian spring oilseed rape (Brassica napus). Weed Research 44: 97-106.

Haile, T.A. \& Shirtliffe, S.J. 2014. Effect of harvesting time on dormancy induction in canola seeds. Weed Science 62: 548-554.

Haile, T.A., Holzapfel, C.B. \& Shirtliffe, S.J. 2013. Canola genotypes and harvest methods affect seedbank addition. Agronomy Journal 106: 236-242.

Honek, A. \& Martinkova, Z. 2001. Aggregation of ground beetles (Carabidae, Coleoptera) on winter rape seeds dispersed on the ground. Plant Protection Science 37: 97-102.

Hyvönen, T., Ketoja, E. \& Salonen, J. 2003. Changes in abundance of weeds in spring cereal fields in Finland. Weed Research 43 : 348-356.

Ilobson, R.N. \& Bruce, D.M. 2002. Seed loss when cutting a standing crop of oilseed rape with two types of combine harvester header. Biosystems Engineering 81: 281-286.

ISO 8210 Standard 1989. Equipment for harvesting - Combine harvesters - Test Procedure. The International Organization for Standardization. 7 p.

Krato, C. \& Petersen, J. 2012. Gene flow between imidazolinone-tolerant and-susceptible winter oilseed rape varieties. Weed Research 52: 187-196.

Lopez-Granados, F. \& Lutman, P.J.W. 1998. Effect of environmental conditions on the dormancy and germination of volunteer oilseed rape seed (Brassica napus). Weed Science 46: 419-423.

Lutman, P.J.W., Berry, K., Payne, R.W., Simpson, E., Sweet, J.B., Champion, G.T., May, M.J., Wightman, P., Walker, K. \& Lainsbury, M. 2005. Persistence of seeds from crops of conventional and herbicide tolerant oilseed rape (Brassica napus). Proceedings of the Royal Society B: Biological Sciences 272: 1909-1915.

Lutman, P.J.W., Freeman, S.E. \& Pekrun, C. 2003. The long-term persistence of seeds of oilseed rape (Brassica napus) in arable fields. Journal of Agricultural Science 141: 231-240.

Messean, A., Sausse, C., Gasquez, J. \& Darmency, H. 2007. Occurrence of genetically modified oilseed rape seeds in the harvest of subsequent conventional oilseed rape over time. European Journal of Agronomy 27: 115-122.

Momoh, E.J.J., Zhou, W.J. \& Kristiansson, B. 2002. Variation in the development of secondary dormancy in oilseed rape genotypes under conditions of stress. Weed Research 42: 446-455.

Mustonen, L., Peltonen-Sainio, P. \& Pahkala, K. 2009. Risk assessment for volunteer and seedling GM potatoes in the northernmost European growing areas. Acta Agriculturae Scandinavica, B Soil and Plant Science 59: 552-558.

Nagel, M., Rosenhauer, M., Willner, E., Friedt, W., and Börner, A. 2011. Seed longevity in oilseed rape (Brassica napus L.) - genetic variation and QTL mapping. Plant Genetic Resources: Characterisation \& Utilisation 9: 260-263.

$\emptyset$ stergaard, L., Kempin, S.A., Bies, D., Klee, H.J. \& Yanofsky, M.F. 2006. Pod shatter-resistant Brassica fruit produced by ectopic expression of the FRUITFULL gene. Plant Biotechnology Journal 4: 45-51.

Pahkala, K. \& Sankari, H. 2001. Seed loss as a result of pod shatter in spring rape and spring turnip rape in Finland. Agricultural and Food Science in Finland 10: 209-216.

Pekrun, C., Lutman, P.J.W. \& Baeumer, K. 1997. Germination behaviour of dormant oilseed rape seeds in relation to temperature. Weed Research 37: 419-431.

Pekrun, C., Lutman, P.J.W., Büchse, A., Albertini, A. \& Claupein, W. 2006. Reducing potential gene escape in time by appropriate post-harvest tillage - Evidence from field experiments with oilseed rape at 10 sites in Europe. European Journal of Agronomy 25: 289-298.

Peltonen-Sainio, P., Hakala, K., Jauhiainen, L. \& Ruosteenoja, K. 2009c. Comparing regional risks in producing turnip rape and oilseed rape - Impacts of climate change and breeding. Acta Agriculturae Scandinavica, B Soil and Plant Science 59: 129-138.

Peltonen-Sainio, P., Hannukkala, A., Huusela-Veistola, E., Voutila, L., Valaja, J., Niemi, J.K., Jauhiainen, L. \& Hakala, K. 2013. Potential and realities of enhancing rapeseed- and grain legume-based protein production in a northern climate. Journal of Agricultural Science 151: 303-321.

Peltonen-Sainio, P., Jauhiainen, L., Hakala, K. \& Ojanen, H. 2009a. Climate change and prolongation of growing season: changes in regional potential for field crop production in Finland. Agricultural and Food Science 18: 171-190.

Peltonen-Sainio, P., Jauhiainen, L. \& Hannukkala, A. 2007. Declining rapeseed yields in Finland: how, why and what next? Journal of Agricultural Science 145: 587-598.

Peltonen-Sainio, P., Känkänen, H., Pahkala, K., Salo, Y., Huusela-Veistola, E. \& Peltonen, J. 2006. Polymer coated turnip rape seed did not facilitate early broadcast sowing under Finnish growing conditions. Agricultural and Food Science 15: 152-165.

Peltonen-Sainio, P. \& Niemi, J.K. 2012. Protein crop production at the northern margin of farming: To boost, or not to boost. Agricultural and Food Science 21: 370-383. 
Peltonen-Sainio, P., Rajala, A., Känkänen, H. \& Hakala, K. 2009b. Improving farming systems in northern European conditions. In: Sadras, V.O. \& Calderini, D. (eds). Crop Physiology: Applications for Genetic Improvement and Agronomy, Amsterdam, The Netherlands: Elsevier. p. 71-97.

Raman, H., Raman, R., Kilian, A., Detering, F., Carling, J., Coombes, N., Diffey, S., Kadkol, G., Edwards, D., McCully, M., Ruparao, P., Parkin, I.A.P, Batley, J., Luckett, D.J. \& Wratten N. 2014. Genome-wide delineation of natural variation for pod shatter resistance in Brassica napus. PLOS ONE 9: e101673.

Rubel, F. \& Kottek, M. 2010. Observed and projected climate shifts 1901-2100 depicted by world maps of the Köppen-Geiger climate classification. Meteorologische Zeitschrift 19: 135-141.

Salonen, J., Hyvönen, T. \& Jalli, H. 2011. Composition of weed flora in spring cereals in Finland - a fourth survey. Agricultural and Food Science 20: 245-261.

Salonen, J., Hyvönen, T., Kaseva, J. \& Jalli, H. 2013. Impact of changed cropping practices on weed occurrence in spring cereals in Finland - a comparison of surveys in 1997-1999 and 2007-2009. Weed Research 53: 110-120.

Schatzki, J., Allam, M., Klöppel, C., Nagel, M., Börner, A. \& Möllers, C. 2013. Genetic variation for secondary dormancy and seed longevity in a set of black-seeded European winter oilseed rape cultivars. Plant Breeding 132: 174-179.

Solantie, R. 2012. The role of climate and related nature conditions in the history of the Finnish settlement and agriculture. University of Jyväskylä, Studies in Humanities 196. 307 p.

Stein, A.J. \& Rodriguez-Cerezo, E. 2009. The global pipeline of new GM crops. Implications of asynchronous approval for international trade. JRC Scientific and Technical Reports. 113 p. Online at ftp://ftp.jrc.es/pub/EURdoc/JRC51799.pdf

Trnka, M., Olesen, J.E., Kersebaum, K.C., Skjelvåg, A.O., Eitzinger, J., Seguin, B., Peltonen-Sainio, P., Rötter, R., Iglesias, A., Orlandini, S., Dubrovský, M., Hlavinka, P., Balek, J., Eckersten, H., Cloppet, E., Calanca, P., Gobin, A., Vucetic V., Nejedlik, P., Kumar, S., Lalic, B., Mestre, A., Rossi, F., Kozyra, J., Alexamdrov, V., Semerádová, D. \& Zalud, Z. 2011. Agroclimatic conditions in Europe under climate change. Global Change Biology 17: 2298-2318.

Varis, R. \& Pehkonen, A. 1989. Leikkuupuimurin pöytätappiot. Helsingin yliopisto, Maatalousteknologian laitos. Tutkimustiedote 58. 39 p. (in Finnish)

Vollman, J., Wagentristl, H. \& Hartl, W. 2010. The effects of simulated weed pressure on early maturity soybeans. European Journal of Agronomy 32: 243-248.

Wang, R., Ripley, V.L. \& Rakow, G. 2007. Pod shatter resistance evaluation in cultivars and breeding lines of Brassica napus, B. juncea and Sinapis alba. Plant Breeding 126: 588-595.

Zhu, Y.M., Li, Y.D., Colbach, N., Ma, K.P., Wei, W. \& Mi, X.C. 2012. Seed losses at harvest and seed persistence of oilseed rape (Brassica napus) in different cultural conditions in Chinese farming systems. Weed Research 52: 317-326. 